\title{
Studies on the diversity of macrofungus in Kodaikanal region of Western Ghats, Tamil Nadu, India
}

\author{
BOOBALAN THULASINATHAN ${ }^{1}$, MOHAN RASU KULANTHAISAMY ${ }^{1,2}$, ARUMUGAM NAGARAJAN ${ }^{1}$, \\ SARAVANAN SOORANGKATTAN ${ }^{3}$, JOTHI BASU MUTHURAMALINGAM ${ }^{3}$, \\ JEYAKANTHAN JEYARAMAN ${ }^{4}$, ALAGARSAMY ARUN ${ }^{1, \bullet}$ \\ ${ }^{1}$ Department of Microbiology, Alagappa University, College Road, Alagappa Puram, Karaikudi - 630003, Tamil Nadu, India. \\ Tel.: +91-4565-223 100, `email: arunalacha@gmail.com \\ ${ }^{2}$ Department of Energy Science, Alagappa University. Karaikudi 630003, Tamil Nadu, India \\ ${ }^{3}$ Department of Botany (DDE), Alagappa University. Karaikudi 630003, Tamil Nadu, India \\ ${ }^{4}$ Department of Bioinformatics, Alagappa University. Karaikudi 630003, Tamil Nadu, India
}

Manuscript received: 22 October 2018. Revision accepted: 13 November 2018.

\begin{abstract}
Boobalan T, Mohan Rasu K, Arumugam N, Saravanan S, Jothi Basu M, Jeyakanthan J, Arun A. 2018. Studies on the diversity of macrofungus in Kodaikanal region of Western Ghats, Tamil Nadu, India. Biodiversitas 19: 2283-2293. We have demonstrated the distribution of macro fungal communities in the selected forest territory of Kodaikanal (Poondi) region, which houses about 100 mushrooms species diverse forms of mushrooms including both the soil-inhabiting $(\mathrm{n}=45)$ and wood-inhabiting $(\mathrm{n}=55)$ species. Kodaikanal is situated on a plateau between the Parappar and Gundar valleys; this area experiences peculiar lower temperature between $8.2^{\circ} \mathrm{C}$ and $19.7^{\circ} \mathrm{C}$, higher humidity between $92 \%$ and $95 \%$, which in turn enhances the growth of different types of mushrooms throughout the year. However, the peak production and macro fungal flushes were observed during the winter season followed by the northeast monsoon (Oct-Dec 2015). A total of 100 species belonging to 51 families were documented from this study sites. Moreover, some species (e.g., Ganoderma sp and Phellinus sp) persists all around the year in this region. However, some incidents of logging and burning of host trees have resulted in the decline of the macro fungal populations in this region. Hence the present study highlights the diversity of macro fungal population and also suggests their importance as part of biodiversity conservation. $\square$
\end{abstract}

Keywords: Basidiomycetes fungi, mushrooms diversity, soil-inhabiting mushrooms, tree-inhabiting mushrooms

\section{INTRODUCTION}

Mushroom is a seasonal growing macro fungus that plays a vital role in terrestrial ecosystem and functions as decomposers (Hawksworth 2001; Mueller et al. 2007; Prakash 2016; Adeniyi et al. 2018). Fungi are large biodiversity group of microorganism in the ecosystem and consist of about 1.5 million species across the globe, where India ranks third largest fungal diversified country with about 2,70,000 species, next to the largest insect biodiversity (Manoharachary et al. 2005). There are many varieties of mushrooms such as fairy clubs, toadstools, puffballs, stinkhorns, earthstars, bird's nest fungi, jelly fungi and these are generally of saprophytic in nature capable of using wood as a nutrient source by utilizing a ligninolytic enzyme (Karwa and Rai 2010). Mushrooms also play an important role in global carbon cycle, in addition, they are essential to the survival of other organisms in numerous ways, act as source of novel bioactive compounds, biocontrol agents, plant pathogens and are also involved in the degradation process (Arun et al. 2008; Arun and Eyini 2011). Wild mushrooms are also becoming more important for their nutritional, sensory and especially pharmacological characteristics including the significant content of vitamins (Günç Ergönül et al. 2013; Heleno et al. 2010).

In this context, mushrooms have a long history of use in oriental medicine to prevent and fight numerous diseases through a balanced diet (Valverde et al. 2015). It is very important to document and understand the biodiversity at regional, national and global level. Because India is one of the 17 mega diverse countries of the world and biodiversity conservation is the responsibility of every country. According to Ministry of Environment and Forest in India With only $2.4 \%$ of the world's land area, about $16.7 \%$ of the world's human population and $18 \%$ livestock together contribute about $8 \%$ of the known global biodiversity. Recently, Gadgil et al. (2011) have raised voice against the illegal practices that are spoiling the ecosystem and have suggested the need for effective conservation of ecologically sensitive areas in the Western Ghats India. Kodaikanal is covered with a dense forest of Acacia mearnsii (Australian black wattle), eucalyptus and pine, which was introduced in the period of $1960 \mathrm{~s}$ between 1,800 and $2,400 \mathrm{~m}$ of Kodaikanal surrounding regions for households and industry purposes (Rangan et al. 2010). The macrofungal forest diversity has been classified based on three main factors such as terricolous saprotrophic, wood-inhabiting and ectomycorrhizal (EcM) (Kutszegi et al. 2015). Many environmental factors are important drivers for the diversity of macrofungal species richness. Wood-inhabiting fungal communities are host specificity or the amount and diameter (Lonsdale et al. 2008), age (Heilmann-Clausen 2001), decay stage (Heilmann-Clausen et al. 2014), species identity (Küffer et al. 2008), complexity (Heilmann-Clausen 
and Christensen 2005), and spatio-temporal availability of dead wood (Halme et al. 2013). The microclimatic condition and inside $\mathrm{pH}$ of wood also play on important role in macrofungal growth (Salerni et al. 2002).

In this scenario, the aim of the present study is to study the distribution and presence of macro fungal species in the forest patches of the Kodaikanal (Poondi) region. Also that, isolating the sporocarps from mushrooms that were cultivated in the laboratory conditions for numerous studies. From the collection and diversity documentation, we have studied the morphological characters of the mushrooms, host specificity, forest-type preference, seasonal growth pattern and adaptation over lower temperature extremes.

\section{MATERIALS AND METHODS}

\section{Study area}

The present study area is situated about $45 \mathrm{~km}$ eastwards from Kodaikanal (Poondi: 10¹1'11.63"N and 77²0'33.89"E; 1981.2 m) (Jan-Dec 2015) (Figure 1). This area is surrounded by Kodaikanal Wildlife Sanctuary, which is about $60,895.482$ hectares (608.95 sq.km) and consisted of different macro fungal species. Hand held thermo-hygrometer (Mextech ${ }^{\mathrm{TM}}$, Mumbai, India) was used to record the temperature and relative humidity is prevailing in the sampling sites. The average temperature of Kodaikanal was about $15.93^{\circ} \mathrm{C}$ with an average of $17.29^{\circ} \mathrm{C}$ in summer (Mar, May, Jun, Jul and Aug) and mean winter temperature was about $14.1^{\circ} \mathrm{C}$ (Dec, Jan and Feb) with average annual rainfall of 1,650 and $1,800 \mathrm{~mm}$ (Rangan et al. 2010). The main reason for selecting this region as the study area is due to their peculiar climatic features, which enhance the growth of a variety of plants like acacia, eucalyptus and pinus (Jan-Dec 2015), which in turn influences the growth of mushrooms in the study area.

\section{Sampling of macrofungi $\square$}

A group of 6 people, three at each side of the central line walked along transects the length of $20 \mathrm{~m}$ each end and all macro fungi within the transect belt were recorded. We have used meter sticks to describe an area of $2 \mathrm{~m}$ on both sides and walked forward the length of transects observed the type and number of individual of the species (OrtegaMartinez and Martinez-Pena 2008). To avoid the double counting, after complete the first transect the following transects were laid $5 \mathrm{~m}$ intervals. Each macro fungi species within each transect was collected in separate specimen bags in order to avoid spore contamination among the different specimens, and these were photographed in colored and tagged. Morphological features such as size, color, shape, and texture of the sporocarps were recorded as these features might change with drying. Identification of specimen was based on macroscopic and microscopic features.

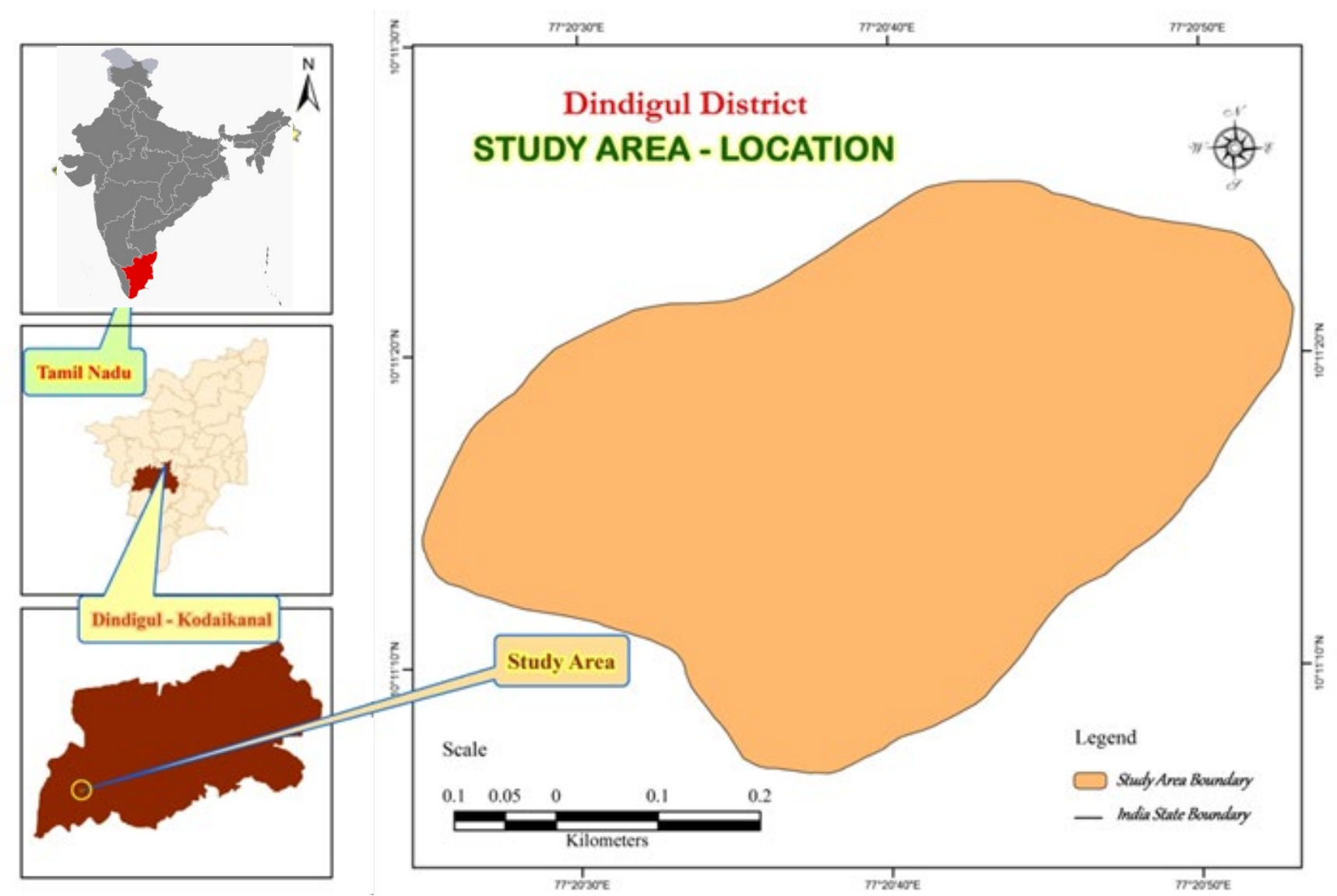

Figure 1. Map showing distribution of mushrooms species in Kodaikanal region of Poondi, India $\square$ 
Table 1. Overall diversity indexes

\begin{tabular}{cccc}
\hline \multicolumn{2}{c}{ Soil habituating } & \multicolumn{2}{c}{ Wood habituating } \\
Shannon-Weiner & Simpson & Shannon-Weiner & Simpson \\
\hline 2.079 & 1.877 & 2.025 & 5.025 \\
& & & \\
\hline
\end{tabular}

The macroscopic features used were: the cap size, shape, color, surface texture and surface moisture, gill color, attachment, spacing, lamellules, the stem size, shape, surface texture and surface moisture, the presence or absence of partial and universal veils, flesh color and texture. Using standard protocols, diversity indices such as Simpson and Shannon-Weiner diversity indices were used (Table 1).

\section{Identification of mushrooms}

The mushrooms were photographed at the collection spot and were identified based on its primary mode of nutrients (fungi parasitic on living plant material), very fresh dead material, wood-decay fungi, ectomycorrhizal fungi and litter-decay fungi found on forest floor according to Ferris et al. (2000) and Takahashi and Kagaya (2005). Identification was also made based on various specific characters such as the diameter of fruiting bodies, cap, odor, flesh, gills, stem and veil (Watling 1971). Furthermore, monographs, identification keys and field guide of mushroom were referred for further species identification (Ostry and O'Brien 2010; Kaul 2001). Apart from that mushrooms were identified and confirmed by their morphological characters using the software identification of mushrooms (Discover mushroom, 1997 - Version: 5.1.2600.5512.); (Det pro, 2000 - Identification of Fungi, Kees Uljé, van Dijkstraat 21, 2405 XE Alphen aan den Rijn, The Netherlands); (Match maker, 2003, Version 1.10).

\section{Phenology of mushrooms}

Phenology studies, i.e., the time-scale between fruit body appearance and disappearance, was monitored bimonthly (throughout the year) and found $80 \%$ of the total species fruit bodies appeared between July to October and disappeared in between March and April. The phenological pattern of appearance and disappearance of fruit bodies were observed to different across species, in soil and wood habiting mushroom. The wood and soil macro fungi with the highest fruiting season (of over 12 months) include Ganoderma applanatum, Ganoderma austral, Ganoderma oregonense, Phellinus igniarius, Phlebia radiate and Pleurotus ostreatus. In soil, Amanita muscaria, Cheilymenia theleboloides, Rhizopogon roseolus, Russula parazurea, Scleroderma areolatum, Scleroderma citrinum, Scleroderma cepa. Similarly, Macro fungi in both wood and soil possess shorter (compressed) or latent fruiting seasons ranging between 1-28 days were mostly members of the family Agaricaceae. The rainy months of August to October marked the peak of fruit body appearance or phenological activity and almost $65 \%$ of all fruit bodies were observed during this period. $\square$

\section{RESULTS AND DISCUSSION}

Among the collected 100 mushroom species 79 were identified at the species level, and 21 were identified as for genus level belonging to 51 families from the Kodaikanal (Poondi) region of the Western Ghats during the study period (2015) (Figures 2-3). Among the species 45 were isolated from the soil host surfaces, whereas the remaining 55 were isolated from the tree host surfaces of tree species such as black wattle $(n=42)$, eucalyptus $(n=3)$, pinus $(n=$ $6)$ and Erythrina indica $(n=4)$. All these host trees were of invasive tree types and were observed to accommodate many number mushrooms than that of the other native tree species. Also, each tree inhabiting mushroom species was observed to dependent only on specific host species.

\section{Diversity and distribution}

A total of 100 species were collected in both wood and soil. Overall diversity index was indicated to wood habituating mushrooms have more index regarding diversity compared with soil habituating mushrooms (Table 1). In Soil the identified species belong to 21 families of 9 orders. Majority of the fungi belonged to the Agaricales (31 species), followed by the boletes ( 8 species) while the Cantharanthales, Pezizales, Physarales, Polyparels, Russulales, and Xylariales were each represented by just a single species. The species abundance of the families was also assessed. The most abundant family was the Agaricaceae with ten species, followed by Psathyrellaceae 7 species, Boletaceae 4 species, Marasmiaceae 3 species, Sclerodermataceae 3 species, Amanitaceae 2 species, Suillaceae 2 species, and others are single species. Whereas in wood identified species belong to 38 families of 14 orders. Among Polyporales 18 species and Agaricales 16 species are contributing in the diversity, followed by others species are single.

Also, the species abundance of the families has also assessed in the soil habitutating fungi. The most abundant family was the Polyporaceae with eight species, followed by Ganodermataceae 4 species, Xylariaceae 3 species, Inocybaceae 2 species, Dacrymycetaceae 2 species, Tricholomataceae 2 species, Pleurotaceae 2 species, and others are present 1 species respectively. From the present study site, macro fungal diversity of about 100 mushrooms belonging to both the soil inhabiting and wood-inhabiting species were documented. The earlier reports suggest that total macro fungal diversity of India is about 850 species (Kakati and Chutia 2009). Similarly, Arun and Eyini 2011 reported the macro fungal diversity of about 132 species from the Thandigudi region of Kodaikanal, Western Ghats. However, those species diversity was quite different from the present study. In this study, we found 75 wood habituating mushrooms species, among 63 mushroom species were sharing rainy and winter season survival, 7 species were surviving all season (All year round) and only 2 were surviving in the dry season. Figure 4 where as in soil, 70 mushroom species were identified, among 62 mushrooms were surviving in both rainy and winter sessions. Only 8 mushroom species were surviving all session (All year round) (Figure 5). 


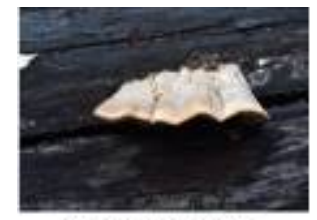

Antradia malicola

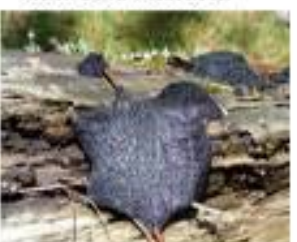

Camarops polysperma

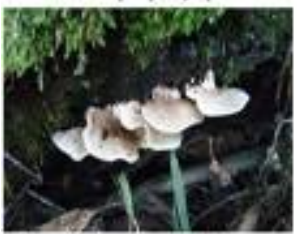

Crepidotus autochthonas

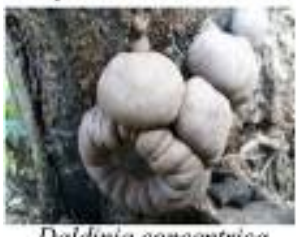

Daldinia concentrica

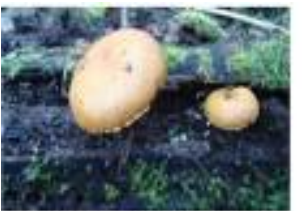

Gymnopilus decipiens

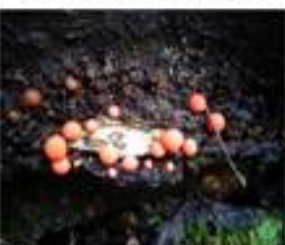

Lycogala terrestre

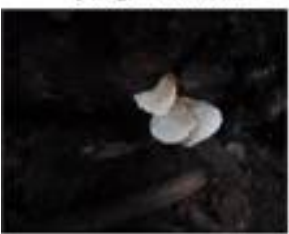

Oligoporus sp

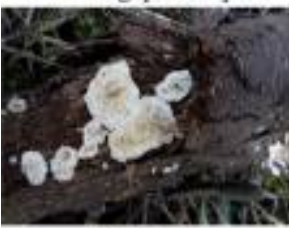

Phlebiasp

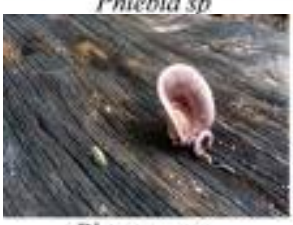

Plesurotus sp

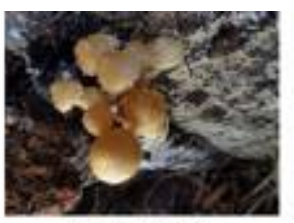

Armillaria sp

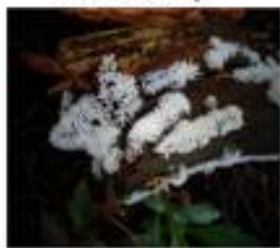

Ceratiomyxa fruticulosa

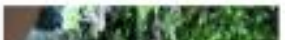

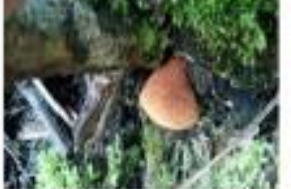
Crepidonis mollis

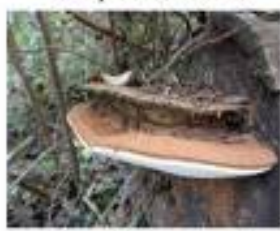

Ganoderma applanatum

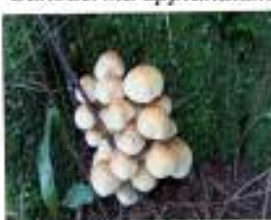

Hypholoma fasciculare

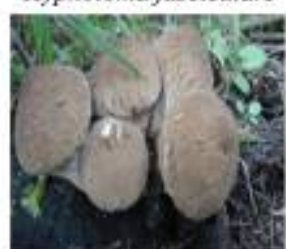

Lycoperdon pyrifome

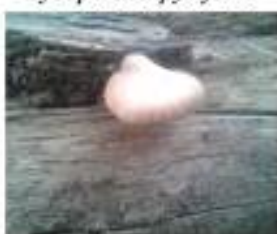

Panellus stipticus

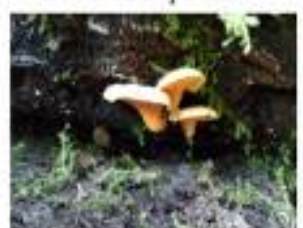

Phyllotopsis nidulans

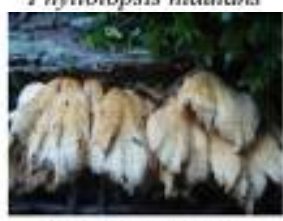

Plicatura crispa
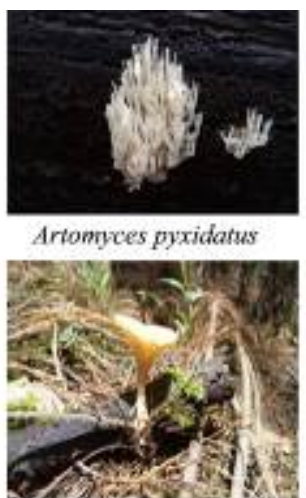

Clitacybe gibba
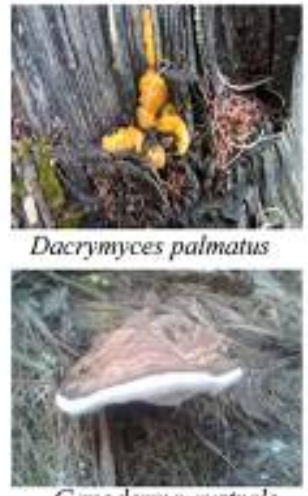

Ganoderna australe

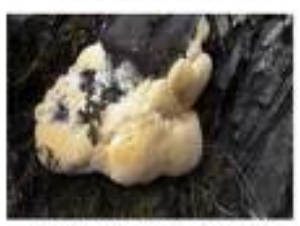

Laefiporus sulphureus

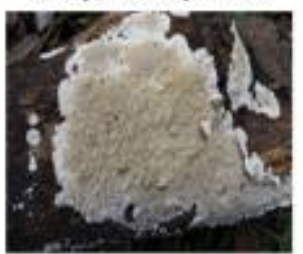

Meruliopsis sp

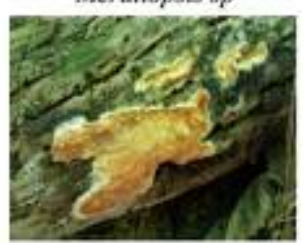

Peniophora incarnata

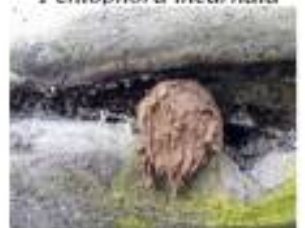

Pisolithus arhizus

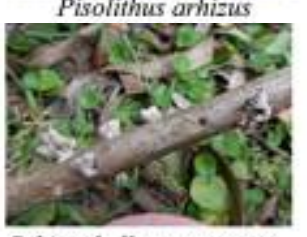

Schizophyllum commune

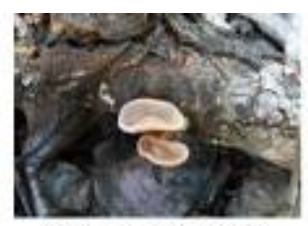

Auricularia auricula

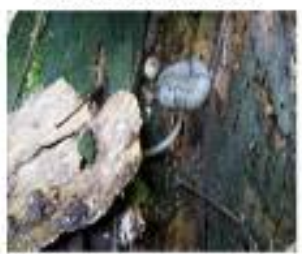

Coprinopsis lagoptes

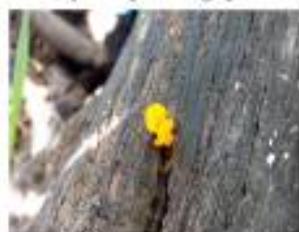

Dacryopinax sp

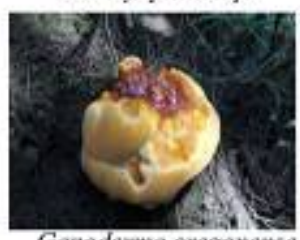

Ganoderma oregonentse

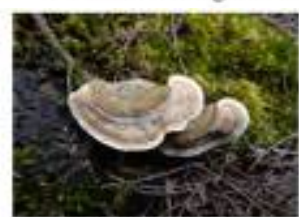

Lenzites betuling

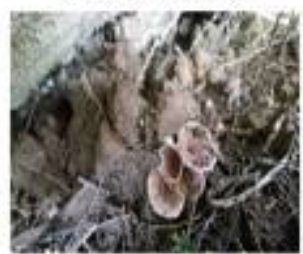

Micromphale perforans

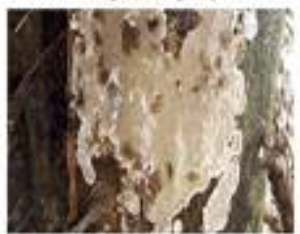

Peniophora rufomarginata

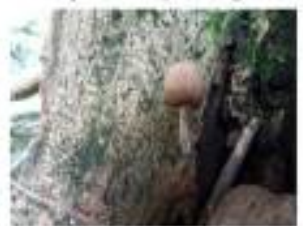

Pluteus cervinus

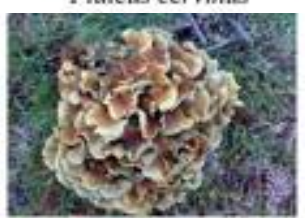

Sparassis crispa

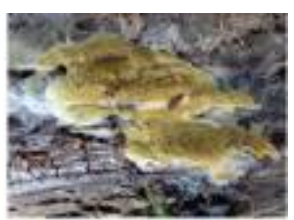

Basidioradulum radula

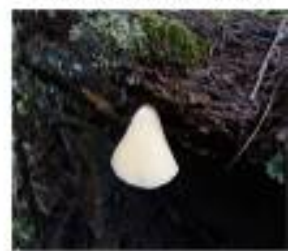

Crepidotus applanatus

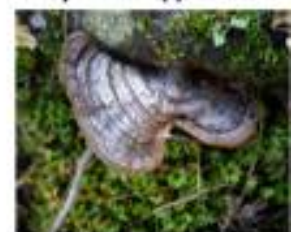

Daedaleopsis confragosa

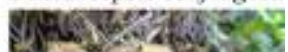
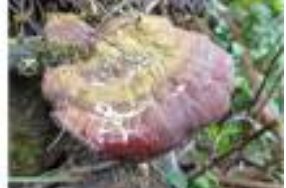

Ganoderna pleifferi

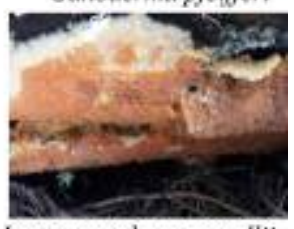

Leucogyrophana romelli

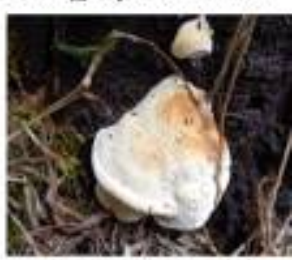

Oligoporis fragilitis

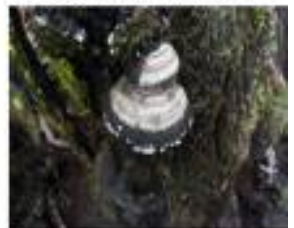

Phellinus sp

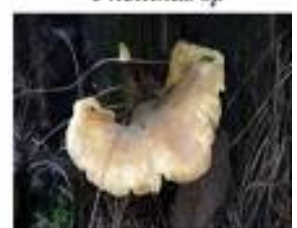

Pleurotus ostreatus

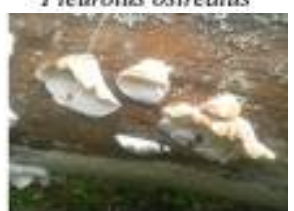

Steccherinum sp 


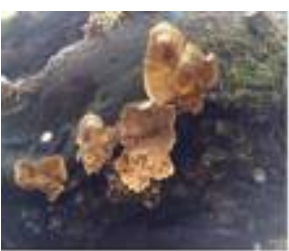

Stereum complicatum

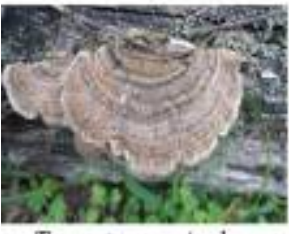

Trametes versicolor

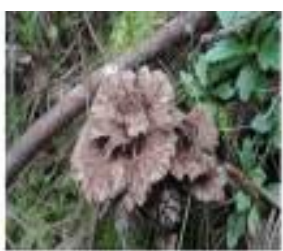

Thelephora terrestris

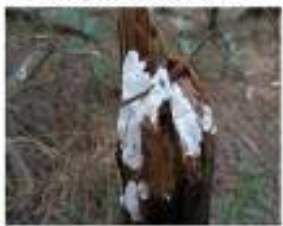

Thechispora molliasca

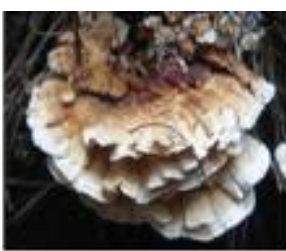

Trametes cervina

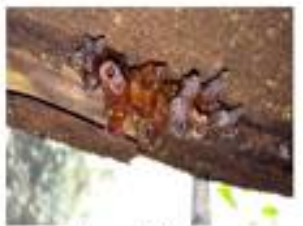

Tremella foliacea

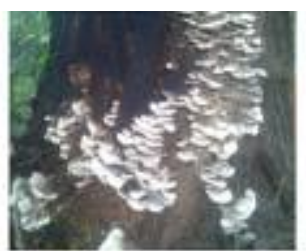

Trametes gibbosa

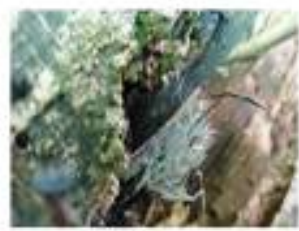

Xylaria sp

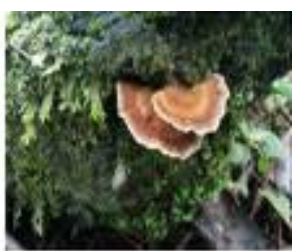

Trametes ochracea

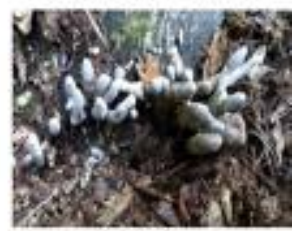

Xylaria sp

Figure 2. Wood-inhabiting mushrooms

\section{Tree inhabiting mushrooms}

Tree host mushrooms were isolated from various wooden surfaces mostly during the rainy seasons. They include 55 species belong to 38 families (Table 2; Figure 2). Moreover, the development of sporocarps was basically observed to dependent on upon natural condition like temperature, precipitation, and dampness. However, some other tree host mushrooms were observed throughout the year (Jan-Dec 2015) (e.g., Ganoderma australe, Ganoderma applanatum and Phellinus sp.) and these species were also observed to be completely appended to the host trees. Hence these mushroom types are also considered as wood spoiling mushrooms.

\section{Soil-inhabiting mushrooms $\square$}

Most of the macro fungal species were isolated from the dirt accumulated soil surfaces and were collected during the wet and dry seasons. The maximum types of mushrooms were isolated during the wet season only (SepDec). They include 45 species belong to 21 families (JanDec 2015) (Table 3; Figure 3). Moreover, these macro fungal flushes were observed to concurrently produce numerous fruit bodies during the downpour as a result of the decrease in the ambient temperature. Conversely, some other macro fungal species such as Amanita muscaria, Russula parazurea, and Scleroderma citrinum were observed throughout the year irrespective of seasons.

\section{Temperature-dependent macrofungal flushes $\square$}

Macro fungal flushes were observed to be a temperature dependent phenomenon, where the abundant growth was observed at winter season (Oct-Dec). Temperature prevailing in this region during the winter season was observed between $8.8^{\circ} \mathrm{C}(\min )$ and $16.9^{\circ} \mathrm{C}(\max )$ (Figure 6 ), with higher humidity range between $92 \%$ and $95 \%$.
Furthermore, the winter season is exactly followed by the northwest monsoon in the months between October and December. Hence it is likely that rain could trigger the germination of the spores and enhance the growth of macro fungal populations. Because the flush of the spores was observed followed by the continuous drizzle or light rain lasting for about 10-15 days. Most of the tree-inhabiting mushrooms were found in the dead matter of woods, and the spores were observed to be germinated from the basal part of the wood where the fall of the direct sunlight is avoided.

Moreover, it was observed that the canopy cover of the trees was acting as a shield and maintaining the optimal microclimate in the places was these kinds of flushes were observed. These observations suggest that lower temperature and continuous rain influences the macro fungal distribution and its abundance. Also, there were few observations on the logging and burning of the host tree resources that has eventually resulted in the depletion of macro fungal populations (Figure 6).

\section{Effects of climatic factors on fungal species richness}

Values of fungal species richness, humidity, and temperature varied significantly during the year. Temperature and humidity showed rather opposing patterns, whereas changes in fungal species richness matched well with changes temperature (Figure 6). Fungal species richness negatively and positively correlated with temperature in soil fungi (Estimate $=-0.01, \mathrm{SE}=0.007$, adj. $\mathrm{R}^{2}=0.11, \mathrm{~T}=-1.9, \mathrm{P}=0.06$, whereas a significant positive correlation was recorded between fungal species richness in wood habitat fungi. Changes in temperature are due to seasonal variation caused by humidity and precipitation. 


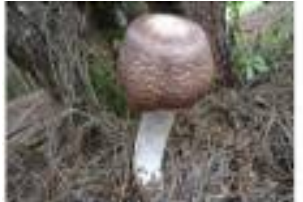

Agaricus placomyces

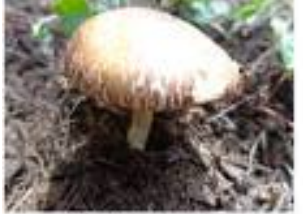

Boletaceae $s p$

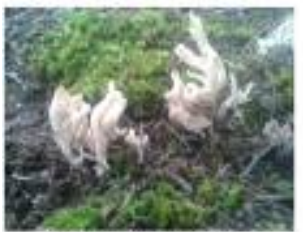

Clavadina negasa

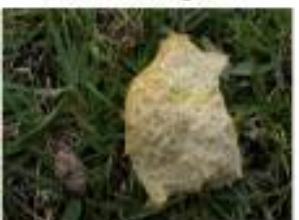

Fuligo septica

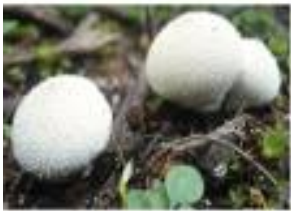

Lycoperdon echinatum

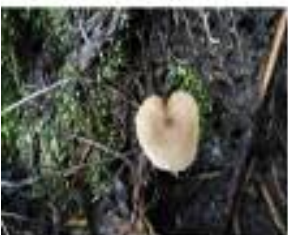

Mycena vitilis

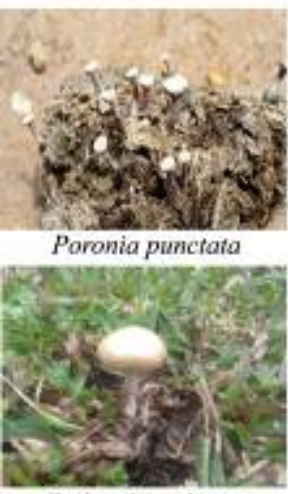

Psilacybe cubensis

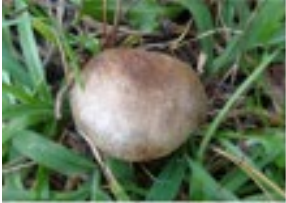

Sclenoderma sp

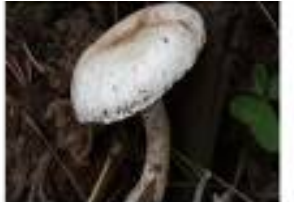

Agaricus sp

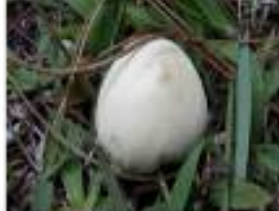

Bovista sp

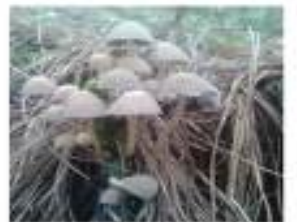

Coprinus disseminatus

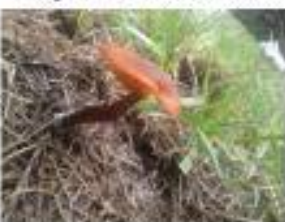

Hygrocybe perplexa

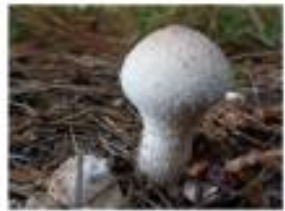

Lycoperdon perlatum

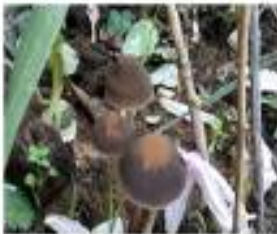

Panacolina focnisecii

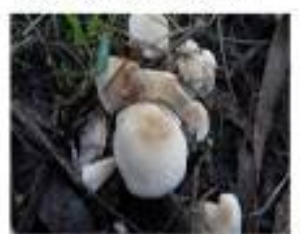

Psathyrella candoleana

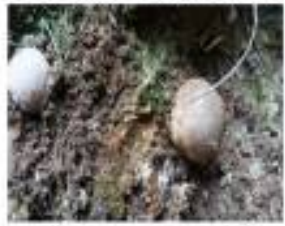

Rhizopogon roseolus

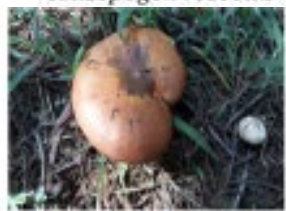

Suillus granulatus

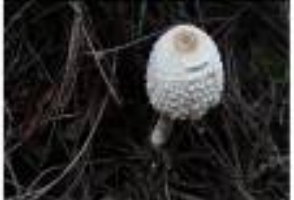

Agaricus sp

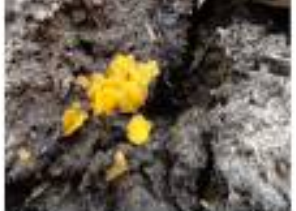

Cheilymenia theleboloides

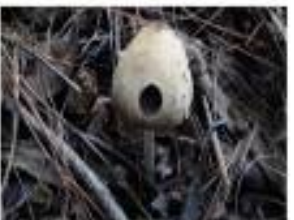

Coprinus domesticus

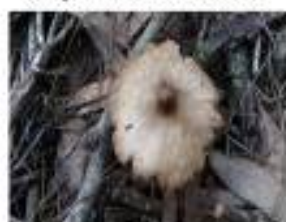

bocyle sororia

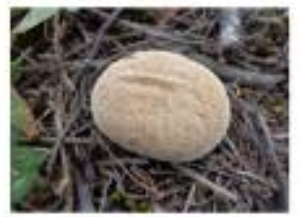

Lycoperdon sp

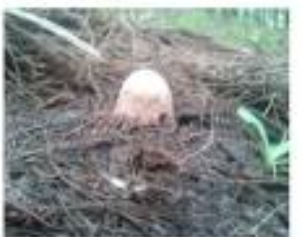

Panaeolus sphinctrinus

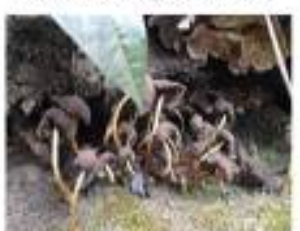

Psathyrella obtusato

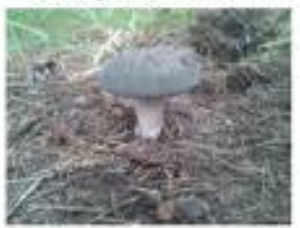

Russula parazured

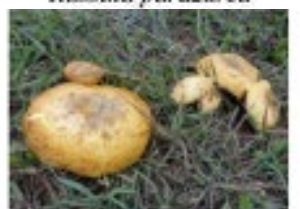

Suillus bovines

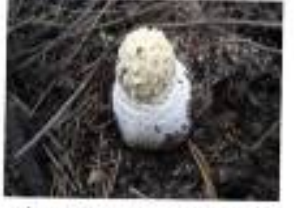

Amanita masniverrucat

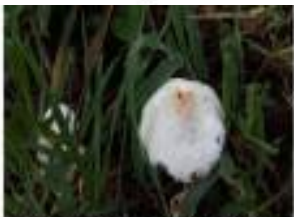

Chlomphyllum molyhdites

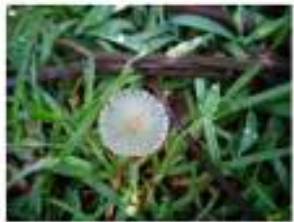

Coprimes plicatilis

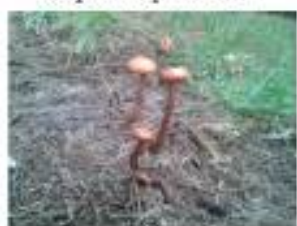

Laccaria proxima

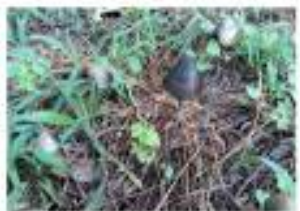

Marasmizs alliaceus

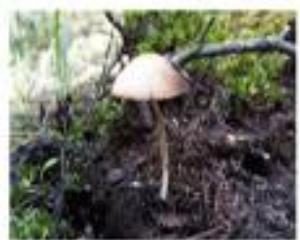

Panaeolus subbalteatus

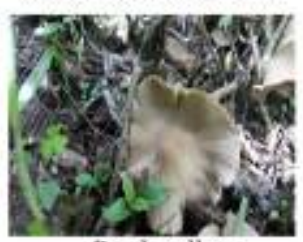

Psathyrellasp

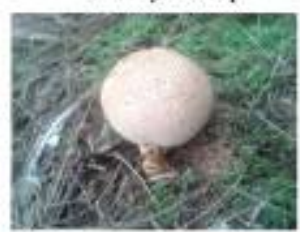

Scleraderma aneolatum

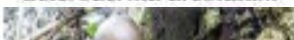

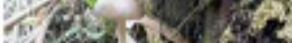
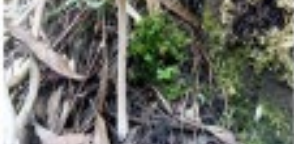

Xenula radicasa

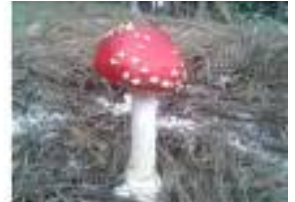

Amanita mascaria

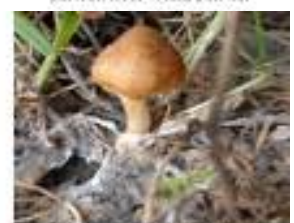

Chroogomphess sp

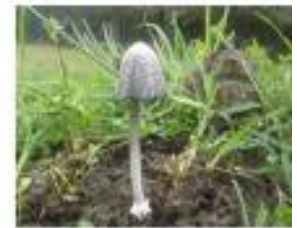

Coprinus sp

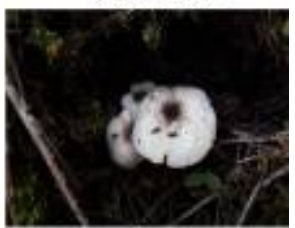

Lepioka brebissoni

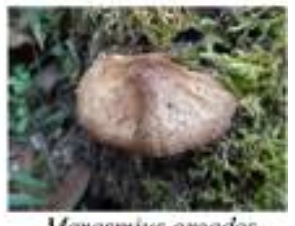

Marasmius oreades

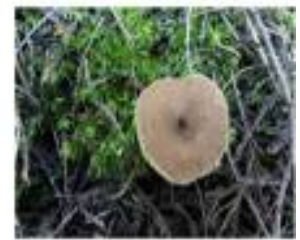

Polyporzes arcularius

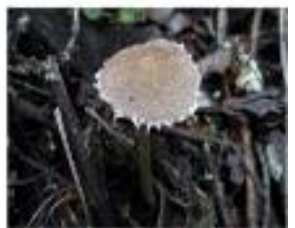

Psathyrella sp

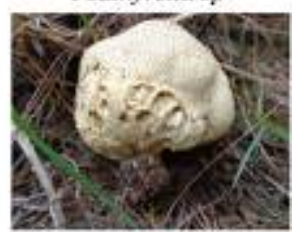

Sclenaderma citrinum

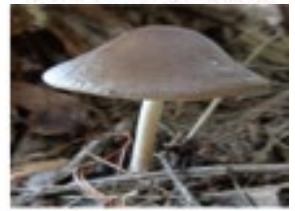

Xerula sp

Figure 3. Soil inhabiting mushrooms 
Table 2. Diversity of wood macrofungi and their phenology, substrate tendency and sociability (WD: Wood Debris, W: Wood)

\begin{tabular}{|c|c|c|c|c|c|c|c|}
\hline Order & Family & Scientific name & $\begin{array}{l}\text { Red data } \\
\text { list }\end{array}$ & $\begin{array}{c}\text { Edible/ } \\
\text { non-edible }\end{array}$ & $\begin{array}{l}\text { No. of } \\
\text { ind. }\end{array}$ & Phenology & Substrate \\
\hline Polyporales & Fomitopsidaceae & Antrodia malicola & NA & Non-edible & 7 & Oct-Dec & WD \\
\hline Agaricales & Physalacriaceae & Armillaria mellea & NA & Edible & 13 & Oct-Nov & WD \\
\hline Russulales & Auriscalpiaceae & Artomyces pyxidatus & NA & Edible & 29 & Oct-Nov & WD \\
\hline Auriculariales & Auriculariaceae & Auricularia auricula & NA & Edible & 31 & Sep-Oct & $\mathrm{W}$ \\
\hline Hymenochaetales & Schizoporaceae & Basidioradulum radula & NA & Non-edible & 20 & Aug-Dec & WD \\
\hline Boliniales & Boliniaceae & Camarops polysperma & NA & Non-edible & 5 & Sep-Oct & WD \\
\hline Protosteliida & Ceratiomyxidae & Ceratiomyxa fruticulosa & NA & Non-edible & 19 & Sep-Oct & WD \\
\hline Agaricales & Tricholomataceae & Clitocybe gibba & NA & Edible & 22 & Aug-Nov & WD \\
\hline Agaricales & Psathyrellaceae & Coprinopsis lagopus & NA & Non-edible & 27 & Sep-Oct & WD \\
\hline Agaricales & Inocybaceae & Crepidotus applanatus & NA & Edible & 9 & Sep-Oct & WD \\
\hline Agaricales & Crepidotaceae & Crepidotus autochthonous & NA & Edible & 51 & Sep-Oct & W \\
\hline Agaricales & Inocybaceae & Crepidotus mollis & NA & Edible & 14 & Sep-Oct & $\mathrm{W}$ \\
\hline Dacrymycetales & Dacrymycetaceae & Dacrymyces palmatus & NA & Non-edible & 25 & Oct-Nov & WD \\
\hline Dacrymycetales & Dacrymycetaceae & Dacrymyces capitatus & NA & Non-edible & 16 & Oct-Dec & WD \\
\hline Polyporales & Polyporaceae & Daedaleopsis confragosa & NA & Non-edible & 10 & Sep-Oct & WD \\
\hline Xylariales & Xylariaceae & Daldinia concentrica & NA & Non-edible & 3 & Oct-Nov & $\mathrm{W}$ \\
\hline Polyporales & Ganodermataceae & Ganoderma applanatum & NA & Non-edible & 47 & TYR & W, WD \\
\hline Polyporales & Ganodermataceae & Ganoderma australe & NA & Non-edible & 61 & TYR & W, WD \\
\hline Polyporales & Ganodermataceae & Ganoderma oregonense & NA & Non-edible & 29 & TYR & W, WD \\
\hline Polyporales & Ganodermataceae & Ganoderma pfeifferi & NA & Non-edible & 35 & Sep-Nov & W, WD \\
\hline Agaricales & Cortinariaceae & Gymnopilus decipiens & NA & Non-edible & 60 & Oct-Nov & $\mathrm{W}$ \\
\hline Agaricales & Strophariaceae & Hypholoma fasciculare & NA & Non-edible & 5 & Oct-Nov & WD \\
\hline Polyporales & Polyporaceae & Laetiporus sulphureus & NA & Non-edible & 23 & TYR & W, WD \\
\hline Polyporales & Polyporaceae & Lenzites betulina & NA & Non-edible & 40 & Sep-Dec & WD \\
\hline Boletales & Hygrophoropsidaceae & Leucogyrophana romellii & NA & Non-edible & 26 & Oct $-\mathrm{Nov}$ & WD \\
\hline Liceida & Tubiferaceae & Lycogala terrestre & NA & Non-edible & 5 & Oct-Nov & W, WD \\
\hline Agaricales & Agaricaceae & Lycoperdon pyriforme & NA & Non-edible & 11 & Oct-Nov & $\mathrm{W}$ \\
\hline Polyporales & Irpicaceae & Meruliopsis taxicola & NA & Non-edible & 14 & Oct-Nov & W, WD \\
\hline Agaricales & Marasmiaceae & Micromphale perforans & NA & Non-edible & 6 & Sep-Nov & WD \\
\hline Polyporales & Polyporaceae & Oligoporus fragilis & NA & Non-edible & 27 & Oct-Nov & W, WD \\
\hline Polyporales & Polyporaceae & Oligoporus caesius & NA & Non-edible & 19 & Sep-Nov & W, WD \\
\hline Agaricales & Mycenaceae & Panellus stipticus & NA & Non-edible & 12 & Sep & WD \\
\hline Russulales & Peniophoraceae & Peniophora incarnata & NA & Non-edible & 5 & Oct-Nov & $\mathrm{W}$ \\
\hline Russulales & Peniophoraceae & Peniophora rufomarginata & NA & Non-edible & 5 & Aug-Dec & W, WD \\
\hline Hymenochaetales & Hymenochaetaceae & Phellinus igniarius & NA & Non-edible & 3 & TYR & $\mathrm{W}, \mathrm{WD}$ \\
\hline Polyporales & Meruliaceae & Phlebia radiata & NA & Non-edible & 10 & TYR & W, WD \\
\hline Agaricales & Tricholomataceae & Phyllotopsis nidulans & NA & Edible & 16 & Oct-Nov & W, WD \\
\hline Boletales & Sclerodermataceae & Pisolithus arhizus & NA & Non-edible & 3 & June-Nov & W, WD \\
\hline Agaricales & Pluteaceae & Pluteus cervinus & NA & Edible & 18 & Oct-Nov & $\mathrm{W}, \mathrm{WD}$ \\
\hline Agaricales & Pleurotaceae & Pleurotus ostreatus & NA & Edible & 71 & Oct-Nov & W, WD \\
\hline Agaricales & Incertae sedis & Plicatura crispa & NA & Non-edible & 7 & Oct-Nov & W, WD \\
\hline Agaricales & Schizophyllaceae & Schizophyllum commune & NA & Non-edible & 33 & Oct-Nov & W, WD \\
\hline Polyporales & Sparassidaceae & Sparassis crispa & NA & Non-edible & 21 & Oct-Nov & WD \\
\hline Polyporales & Steccherinaceae & Steccherinum ochraceum & NA & Non-edible & 5 & Sep-Dec & WD \\
\hline Russulales & Stereaceae & Stereum complicatum & NA & Non-edible & 4 & Aug-Nov & W, WD \\
\hline Thelephorales & Thelephoraceae & Thelephora terrestris & NA & Non-edible & 5 & Oct-Nov & WD \\
\hline Polyporales & Polyporaceae & Trametes cervina & NA & Non-edible & 29 & Oct-Nov & W, WD \\
\hline Polyporales & Polyporaceae & Trametes gibbosa & NA & Non-edible & 40 & Aug-Dec & W, WD \\
\hline Polyporales & Coriolaceae & Trametes ochracea & NA & Non-edible & 22 & Sep-Oct & W, WD \\
\hline Polyporales & Polyporaceae & Trametes versicolor & NA & Non-edible & 55 & Oct-Nov & W, WD \\
\hline Trechisporales & Trechisporaceae & Trechispora mollusca & NA & Non-edible & 20 & Sep-Dec & W, WD \\
\hline Tremellales & Tremellaceae & Tremella foliacea & NA & Edible & 12 & Oct-Nov & W, WD \\
\hline Xylariales & Xylariaceae & Xylaria hypoxylon & NA & Non-edible & 4 & Sep-Oct & WD \\
\hline Xylariales & Xylariaceae & Xylaria polymorpha & NA & Non-edible & 7 & Oct-Nov & WD \\
\hline
\end{tabular}


Table 3. Diversity of soil-inhabiting mushrooms from Western Ghats region in Dindigul District, India (DLL: Decomposing Leaf Litter, S: Soil)

\begin{tabular}{|c|c|c|c|c|c|c|c|}
\hline Order & Family & Scientific name & $\begin{array}{c}\text { Red data } \\
\text { list }\end{array}$ & $\begin{array}{c}\text { Edible/ } \\
\text { non-edible }\end{array}$ & $\begin{array}{c}\text { No. of } \\
\text { ind. }\end{array}$ & Phenology & Substrate \\
\hline Agaricales & Agaricaceae & Agaricus augustus & NA & Edible & 7 & Sep-Nov & DLL \\
\hline Agaricales & Agaricales & Agaricus arrensis & NA & Edible & 19 & Sep-Nov & S \\
\hline Agaricales & Agaricales & Agaricus crocodilinus & NA & Edible & 5 & Sep-Oct & DLL \\
\hline Agaricales & Agaricales & Coprinus comatus & NA & Edible & 4 & Sep-Oct & DLL, $\mathrm{S}$ \\
\hline Agaricales & Amanitaceae & Amanita muscaria & NA & Non-Edible & 23 & TYR & DLL \\
\hline Agaricales & Strophariaceae & Agrocybe praecox & NA & Edible & 11 & Nov-Dec & DLL, S \\
\hline Agaricales & Agaricaceae & Bovista plumbea & NA & Edible & 9 & Oct-Nov & Grass \\
\hline Pezizales & Pyronemataceae & Cheilymenia theleboloides & NA & Non-Edible & 18 & TYR & Cow dung, $\mathrm{S}$ \\
\hline Agaricales & Agaricaceae & Chlorophyllum molybdites & NA & Edible & 15 & Oct-Nov & $\mathrm{S}$ \\
\hline Boletales & Gomphidiaceae & Chroogomphus rutilus & NA & Edible & 21 & Oct-Dec & $\mathrm{S}$ \\
\hline Cantharellales & Clavulinaceae & Clavulina rugosa & NA & Edible & 6 & Oct-Nov & $\mathrm{S}$ \\
\hline Agaricales & Psathyrellaceae & Coprinus disseminatus & NA & Edible & 20 & Oct-Nov & DLL, WD \\
\hline Agaricales & Psathyrellaceae & Coprinus domesticus & NA & Edible & 5 & Oct-Nov & DLL, WD \\
\hline Agaricales & Psathyrellaceae & Coprinus plicatilis & NA & Edible & 10 & Sep-Nov & DLL, $\mathrm{S}$ \\
\hline Physarales & Physaraceae & Fuligo septic & NA & Non-Edible & 4 & Oct-Nov & Grass \\
\hline Agaricales & Hygrophoraceae & Hygrocybe perplexa & NA & Edible & 37 & Oct-Nov & DLL \\
\hline Agaricales & Inocybaceae & Inocybe sororia & NA & Non-Edible & 18 & Oct-Nov & $\mathrm{S}$ \\
\hline Agaricales & Hydnangiaceae & Laccaria proxima & NA & Non-Edible & 32 & Sep-Nov & $\mathrm{S}, \mathrm{DLL}$ \\
\hline Agaricales & Agaricaceae & Lepiota brebissonii & NA & Non-Edible & 17 & Sep-Oct & $\mathrm{S}$ \\
\hline Agaricales & Agaricaceae & Lycoperdon echinatum & NA & Edible & 18 & Sep-Nov & $\mathrm{S}$ \\
\hline Agaricales & Agaricaceae & Lycoperdon perlatum & NA & Edible & 13 & Sep-Dec & $\mathrm{S}$ \\
\hline Agaricales & Marasmiaceae & Marasmius alliaceus & NA & Edible & 22 & Sep-Nov & DLL, S \\
\hline Agaricales & Marasmiaceae & Marasmius oreades & NA & Edible & 3 & Sep-Oct & DLL, $\mathrm{S}$ \\
\hline Agaricales & Marasmiaceae & Mycena vitilis & NA & Non-Edible & 11 & Sep-Oct & DLL, $\mathrm{S}$ \\
\hline Agaricales & Bolbitiaceae & Panaeolina foenisecii & NA & Non-Edible & 23 & Oct-Nov & $\mathrm{S}$ \\
\hline Agaricales & Bolbitiaceae & Panaeolus sphinctrinus & NA & Non-Edible & 15 & Oct-Nov & $\mathrm{S}$ \\
\hline Polyporales & Polyporaceae & Polyporus arcularius & NA & Non-Edible & 13 & Sep-Nov & $\mathrm{S}, \mathrm{DW}$ \\
\hline Xylariales & Xylariaceae & Poronia punctata & NA & Non-Edible & 10 & Sep-Oct & Cow dung \\
\hline Agaricales & Psathyrellaceae & Psathyrella candolleana & NA & Non-Edible & 27 & Sep-Oct & $\mathrm{S}$ \\
\hline Agaricales & Psathyrellaceae & Psathyrella obtusata & NA & Non-Edible & 19 & Sep-Oct & $\mathrm{S}$ \\
\hline Agaricales & Psathyrellaceae & Psathyrella senex & NA & Non-Edible & 14 & Sep-Oct & $\mathrm{S}$ \\
\hline Agaricales & Psathyrellaceae & Psathyrella hirta & NA & Non-Edible & 15 & Aug-Nov & $\mathrm{S}$ \\
\hline Agaricales & Hymenogastraceae & Psilocybe cubensis & NA & Non-Edible & 26 & Sep-Nov & $\mathrm{S}$ \\
\hline Boletales & Rhizopogonaceae & Rhizopogon roseolus & NA & Edible & 9 & TYR & $\mathrm{S}$ \\
\hline Russulales & Russulaceae & Russula parazurea & NA & Edible & 117 & TYR & $\mathrm{S}$ \\
\hline Boletales & Sclerodermataceae & Scleroderma areolatum & NA & Non-Edible & 53 & TYR & $\mathrm{S}$ \\
\hline Boletales & Sclerodermataceae & Scleroderma citrinum & NA & Non-Edible & 39 & TYR & $\mathrm{S}$ \\
\hline Boletales & Sclerodermataceae & Scleroderma cepa & NA & Non-Edible & 25 & TYR & $\mathrm{S}$ \\
\hline Boletales & Suillaceae & Suillus granulatus & NA & Edible & 30 & July-Dec & $\mathrm{S}$ \\
\hline Boletales & Suillaceae & Suillus bovines & NA & Edible & 126 & Sep-Nov & $\mathrm{S}$ \\
\hline Agaricales & Physalacriaceae & Xerula radicata & NA & Edible & 41 & July-Sep & $\mathrm{S}$ \\
\hline
\end{tabular}

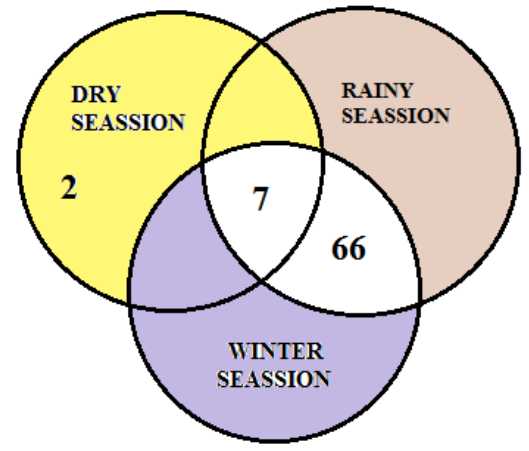

Figure 4. Distribution of wood habitat fungal diversity in the study area $\square$

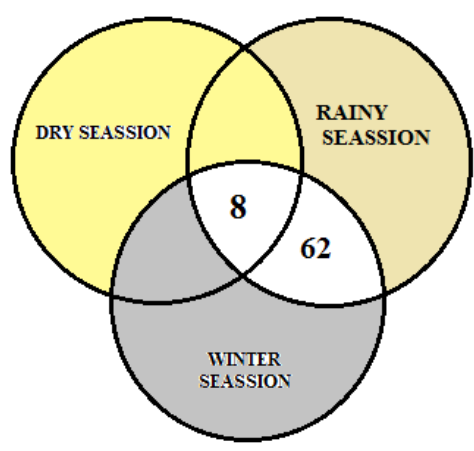

Figure 5. Distribution of soil habitat fungal diversity in the study area $\square$ 

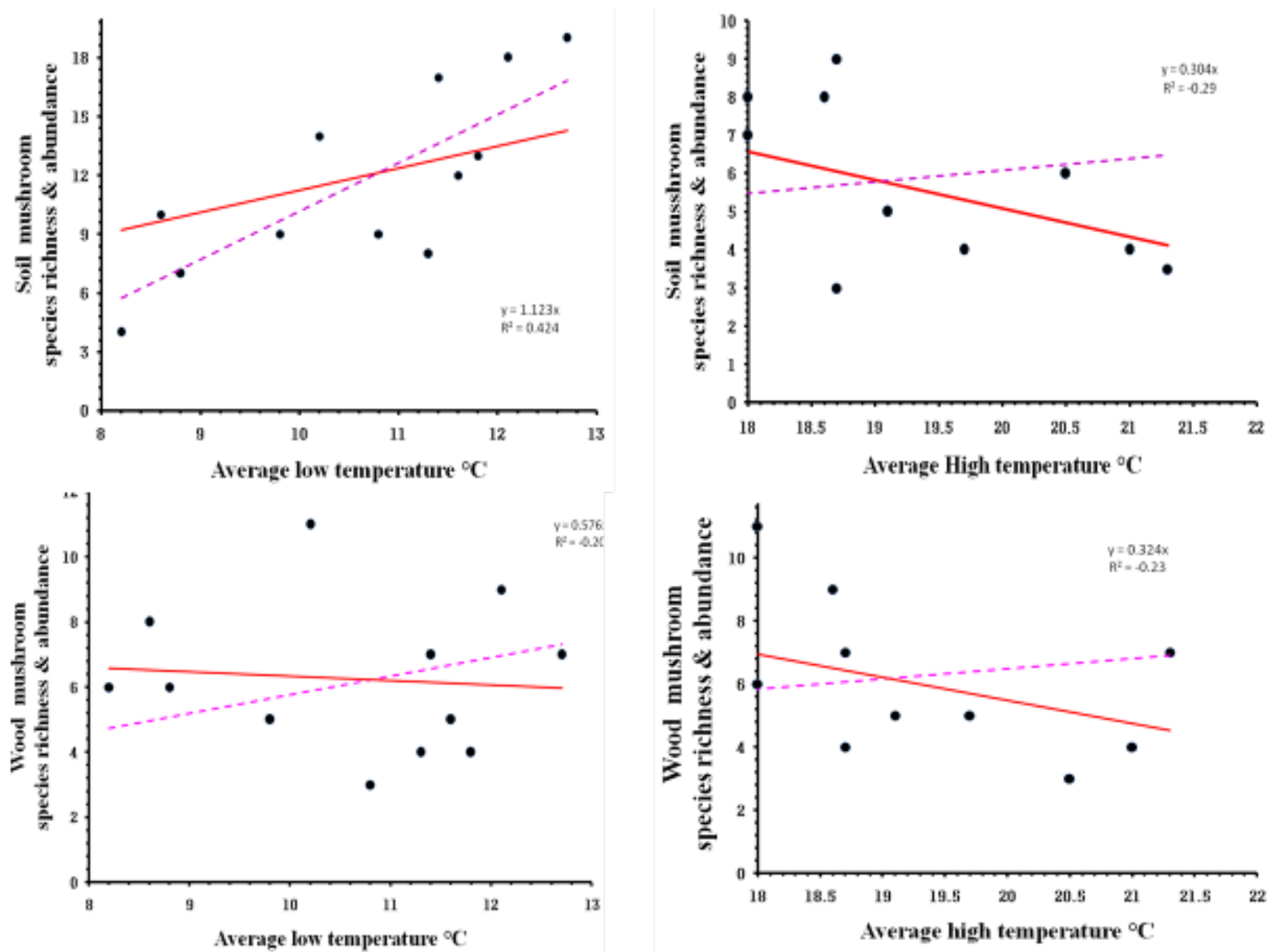

Figure 6. Generalized linear models showing the relationships between climatic variables and fungal species richness during sampling events in the study area

Soil-inhabiting mushrooms were observed to be more during the wet seasons of the year in the dirt accumulated soil surfaces. It was suggested that the fruiting process of macro fungi requires surplus energy and nutrients at the time of their vegetative growth, which is abundant in the dirty soil surfaces (Busch and Braus 2007). Similarly, the tree-inhabiting macro fungi are also observed to be abundant during the wet seasons of the year. Environmental factors such as temperature, humidity and rainfall are reported to influence the formation of sporocarps (Dighton et al. 1981). Soil mushrooms were observed to be abundant in the soil enriched with dead and decaying leaves. There are studies highlighting the importance of dirt richness on the survival and growth of saprobic mushrooms (Packham et al. 2002; Gates et al. 2011). Dirt porosity, type of soil, supplement accessibility and $\mathrm{pH}$ are the important primary components of the dirt development that eventually act as a substrate to the mushrooms (Karwa and Rai 2010). Most importantly, macro fungal flushes seem to be a temperature dependent phenomenon. Because the changes in temperature, precipitation are likely to influence the climate changes (Kauserud et al. 2008) and the factors affecting fruiting are directly and indirectly controlled by the microclimatic features (Yang et al. 2012). In the present study, microclimatic stability was observed to be influenced and maintained by the canopy cover. Greater canopy covers are reported to maintain the humidity at high ranges (Hardwick et al. 2015), and thereby enhances the fungal growth. Moreover, shade tree diversity and forest canopy cover are therefore important in maintaining high fungal diversity and its production (Ostry N. A.; O'Brien, J.G. 2010). Another important factor influencing the macro fungal flushes is drizzle or continuous rain lasting for about 10-15 days. According to Manoharachary et al. (2005) continuous rain could favor rapid growth of macro fungi when organic matter or its decomposition products are easily available. Among the 95 macro fungi species that was observed in the study area, there are a few biodynamic mixes having tremendous medical functions, e.g., Ganoderma sp: anticancer, cell reinforcement, antiviral and antifungal properties (Paterson 2006). Based on the study we observed that some of the mushroom species (Coprinus sp., Amanita muscaria, Agaricus sp., scleroderma sp.) were abundantly present soil and wood surfaces throughout the year, whereas the organisms such as (Ganoderma pfeifferi, 
Thelephora terrestris, Lycoperdon sp., Ganoderma oregonense) were observed in very rarely in few areas. We also observed that the forest fire has substantially reduced the biodiversity of mushrooms. Thus it should be avoided to restore the biodiversity of mushrooms. Hattori (2001) also insists the deforestation and firing could spoil the biodiversity of mushrooms to an unpredictable extent. Macro fungal biodiversity protection is crucial to other environmental biodiversity. In this scenario, it is very important to pay attention to the ecologically sensitive areas, which confronts the dangers due to mismanagement (Gadgil et al. 2011). Macro fungal species are not only beautiful but also play crucial roles in decomposition, nutrient cycling, contribute to soil structure, health, fruiting bodies provide food and medicinally valuable compounds (Maser et al. 2008). They are vital to the forest ecosystem and are to be essentially conserved.

In conclusions, mushrooms are vital to break down the organic matter and recycling nutrients of ecosystems. In conservation biology macrofungi are the interface of organisms between life and death-without them, all ecosystems would fail. In the diversity analysis, 11 macrofungus from wood and 22 soil habitats are edible and frequently used by the scheduled tribes of the study area. The nonedible mushrooms of wood habitat like Polyporales and Hymenochaetales are have been used for the treatment of cancer because of the presence of their bioactive compounds. These wood habitat mushrooms were recorded to be high in their numbers compared to soil habitat. Among the wood habitat, the dominant family was identified as Agaricaceae. Even though these wood habitats are high, their economic value is yet to study well. In soil habitat is dominated by the family of Polyporales and Agaricaceae equally. Compared to wood habitat, edibility of soil mushroom is high because of easy accessibility and availability. This soil habitat also holding considerable no of nonedible mushrooms, they also used for the treatment of cancer, wound healing. ie., medicinal value. An extensive study in Poondi, Kodaikanal region of Western Ghats helps to explore the useful metabolites from these mushrooms for the benefit of mankind. $\square$

\section{REFERENCES}

Adeniyi M, Odeyemi Y, Odeyemi O. 2018. Ecology, diversity and seasonal distribution of wild mushrooms in a Nigerian tropical forest reserve. Biodiversitas 19: 285-295

Arun A, Eyini M. 2011. Comparative studies on lignin and polycyclic aromatic hydrocarbons degradation by basidiomycetes fungi. Bioresour Technol 102: 8063-8070.

Arun A, Raja PP, Arthi R, Ananthi M, Kumar KS, Eyini M. 2008. Polycyclic aromatic hydrocarbons (PAHs) biodegradation by basidiomycetes fungi, Pseudomonas isolate, and their cocultures: Comparative in vivo and in silico approach. Appl Biochem Biotechnol 151: 132-142.

Busch S, Braus GH. 2007. How to build a fungal fruit body: From uniform cells to specialized tissue. Mol. Microbiol. 6:873-6.

Ferris R, Peace AJ, Humphrey JW, Broome AC. 2000. Relationships between vegetation, site type and stand structure in coniferous plantations in Britain. For Ecol Manage.136: 35-51

Gadgil M, Daniels R, Ganeshaiah RJ, Narendra Prasad KN, Murthy S, Jha MSR, Ramesh CS, Subramanian BR, KA. 2011. Mapping ecologically sensitive, significant and salient areas of Western Ghats: Proposed protocols and methodology. Curr Sci 100: 175-182.

Günç Ergönül P, Akata I, Kalyoncu F, Ergönül B. 2013. Fatty acid compositions of six wild edible mushroom species. Sci World J 2013: 163964. DOI: 10.1155/2013/163964.

Halme P, Ódor P, Christensen M, Piltaver A, Veerkamp M, Walleyn R, Siller I, Heilmann-Clausen J. 2013. The effects of habitat degradation on metacommunity structure of wood-inhabiting fungi in European beech forests. Biol Conserv 168: 24-30

Hattori T .2001. Type studies of the polypores described by E. J. H. Corner from Asia and West Pacific Areas II*. Species described in gloeophyllum, heteroporus, microporellus, oxyporus, paratrichaptum, and rigidoporus. Mycoscience 42: 19-28

Hawksworth DL. 2001. Mushrooms: The Extent of the Unexplored Potential. Intl J Med Mushrooms 3: 333-337.

Heilmann-Clausen J, AudeE, van Dort K, Christensen M, Piltaver A, Veerkamp M, WalleynR, Siller I, Standovár T, Òdor P. 2014. Communities of wood-inhabiting bryophytes and fungi on dead beech logs in Europe-reflecting substrate quality or shaped by climate and forest conditions? J Biogeogr 41: 2269-2282

Heilmann-Clausen J, Christensen M. 2005. Wood-inhabiting macrofungi in Danish beech-forests-Conflicting diversity patterns and their implications in a conservation perspective. Biol Conserv 122: 633642

Heilmann-Clausen J. 2001. A gradient analysis of communities of macrofungi and slime moulds on decaying beech logs. Mycol Res 105: 575-596.

Heleno SA, Barros L, Sousa MJ, Martins A, Ferreira ICFR. 2010. Tocopherols composition of Portuguese wild mushrooms with antioxidant capacity. 119: 1443-1450.

Kakati LN, Chutia BC. 2009. Diversity and ecology of wild sericigenous insects in Nagaland, India. Trop Ecol 50:137-146.

Karwa A, Rai M. 2010. Tapping into the edible fungi biodiversity of Central India. Biodiversitas 11: 97-101.

Kaul TN. 2001. Biology and Conservation of Mushrooms. New Delhi, India: Oxford \& IBH Publishing Co. Pvt. Ltd. 117-145.

Kauserud H, Stige LC, Vik JO, Okland RH, Hoiland K, Stenseth NC. 2008. Mushroom fruiting and climate change. Proc Natl Acad Sci. 105: 3811-3814.

Küffer N, Gillet F, Senn-Irlet B, Aragno M, Job D. 2008. Ecological determinants of fungal diversity on dead wood in European forests. Fungal Divers 30: 83-95.

Kutszegi G, Siller I, Dima B, Takács K, Merényi Z, Varga T, Turcsányi G, Bidló A, Ódor P. 2015. Drivers of macrofungal species composition in temperate forests, West Hungary: Functional groups compared. Fungal Ecol 17: 69-83.

Lonsdale D, Pautasso M, Holdenrieder O. 2008. Wood-decaying fungi in the forest: Conservation needs and management options. Eur J For Res 127: 1-22.

Manoharachary C, Sridhar K, Singh R, Adholey A, Suryanarayanan TS, Rawat S, Johri BN. 2005. Fungal biodiversity: Distribution, conservation and prospecting of fungi from India. Curr Sci 89: 58-71.

Maser C, Claridge AW, Trappe JM. 2008. Trees, truffles and beasts? How forests function. Rutgers University Press, New Brunswick, N.J.

Mueller GM, Schmit JP, Leacock PR, Buyck B, Cifuentes J, Desjardin DE, Halling RE, Hjortstam K, Iturriaga T, Larsson KH, Lodge DJ, May TW, Minter D, Rajchenberg M, Redhead SA, Ryvarden L, Trappe JM, Watling R, Wu Q. 2007. Global diversity and distribution of macrofungi. Biodivers Conserv 16: 37-48.

Ortega-Martínez P, Fernando Martínez-Peña. 2008. A sampling method for estimating sporocarps production of wild edible mushrooms of social and economic interest. Invest Agrar: Sist Recur For 17: 228237.

Ostry ME, Anderson NA, O'Brien JG. 2010. Field guide to common macrofungi in eastern forests and their ecosystem functions. USDA For Serv North Res Stn Gen Tech Rep. doi: 10.2737/NRS-GTR-79

Packham JM, May TW, Brown MJ, Wardlaw TJ, Mills AK. 2002. Macrofungal diversity and community ecology in mature and regrowth wet eucalypt forest in Tasmania: A multivariate study. Austral Ecol. 27: 149-161

Paterson RRM. 2006. Ganoderma - A therapeutic fungal biofactory. Phytochemistry 67:1985-2001

Prakash PY. 2016. A couplet tribute to fungi. Curr. Sci.110

Rangan H, Kull CA, Alexander L. 2010. Forest plantations, water availability, and regional climate change: Controversies surrounding 
Acacia mearnsii plantations in the upper Palnis Hills, southern India. Reg Environ Chang 10: 103-117.

Salerni E, Laganà A, Perini C, Loppi S, Dominicis V De. 2002. Effects of temperature and rainfall on fruiting of macrofungi in oak forests of the Mediterranean area. Isr J Plant Sci 50: 189-198.

Takahashi KH, Kagaya T. 2005. Guild structure of wood-rotting fung based on volume and decay stage of coarse woody debris. Ecol Res.20: 215-222
Valverde ME, Hernández-Pérez T, Paredes-López O. 2015. Edible mushrooms: Improving human health and promoting quality of life. Intl J Microbiol 2015: 376387. DOI: 10.1155/2015/376387.

Watling R.1971. Chemical tests in agaricology. Methods Microbiol 4: 567-597

Yang X, Luedeling E, Chen G, Kevin D. Hyde, Yang Y, Zhou D, Xu J, Yang Y. 2012. Climate change effects fruiting of the prize matsutake mushroom in China. Fungal Divers 56: 189-198. 